\title{
Studies on Impact of Organic, Inorganic and Integrated Source of Nutrients on Growth, Yield, Quality and Nutrient Uptake of Okra (Abelmoschus esculentus) and Soil Microbiological Properties
}

\author{
N. K. Badhan, N. Datt ${ }^{*}$ and R. P. Sharma \\ Department of Soil Science, Chaudhary Sarvan Kumar Himachal Pradesh Krishi \\ Vishvavidyalaya, Palampur, Himachal Pradesh, India \\ *Corresponding author
}

\section{Keywords \\ Organic, Inorganic and integrated use, Okra, Yield, Quality parameters, Nutrient efficiency ratios, Soil microbiological properties, Correlation}

\section{Article Info}

Accepted: 16 November 2020 Available Online: 10 December 2020

\section{A B S T R A C T}

A field experiment was conducted with 11 treatments and three replications in randomized block design on Okra in an acid Alfisol during the year 2005 at the research farm of Department of Soil Science, Chaudhary Sarvan Kumar Himachal Pradesh Krishi Vishvavidyalaya, Palampur. The maximum plant height was recorded with the application of farmyard manure in combination with 100 percent nitrogen, phosphorus and potassium ( $100 \% \mathrm{NPK}$ i.e. $75 \mathrm{~N}, 50 \mathrm{P}_{2} \mathrm{O}_{5}$ and $50 \mathrm{~kg} \mathrm{ha}^{-1} \mathrm{~K}_{2} \mathrm{O}$ ) followed by 100 percent NPK + vermicompost @10 t ha ${ }^{-1}$ which was 45.8 and 22.8 percent higher than 100 percent NPK application alone. However yield, nutrient uptake and mineral contents were maximum with vermicompost @ $10 \mathrm{t} \mathrm{ha}^{-1}+100 \%$ NPK and statistically at par with biocompost at same rate $+100 \%$ NPK. There was 65 and $46.9 ; 245$ and 235 percent increase in fruit yield with the application of vermicompost in combination with $100 \%$ NPK in comparison to $100 \%$ NPK alone and control treatments, respectively. Almost similar results were obtained with biocompost @ $10 \mathrm{t} \mathrm{ha}^{-1}$ along with 100\% NPK application. Each biocompost and vermicompost @ $5 \mathrm{t}$ along with 100\%NPK gave equivalent yield to $100 \% \mathrm{NPK}+10 \mathrm{t} \mathrm{FYM} \mathrm{ha}^{-1}$. It is evident that the quantity of farmyard manure can be reduced to half with the use of either vermicompost or biocompost. Likewise yield, maximum mineral content viz., $\mathrm{P}, \mathrm{K}, \mathrm{Ca}, \mathrm{Mg}$ and $\mathrm{Fe}$ were found in $100 \%$ $\mathrm{NPK}+10 \mathrm{t} \mathrm{ha}^{-1}$ vermicompost which were at par with 100\% NPK + biocompost @ $10 \mathrm{t} \mathrm{ha}^{-1}$ and 100\% NPK+ FYM $10 \mathrm{t} \mathrm{ha}^{-1}$ and minimum in the control. The mineral contents were significantly increased with the combined use of biocompost/ vermicompost with $100 \%$ NPK than the alone application of either biocompost/ vermicompost or 100\% NPK. The increase in nitrogen uptake both in fruit and stalk in $100 \%$ $\mathrm{NPK}+10 \mathrm{t} \mathrm{ha}^{-1}$ vermicompost was 67.7 and 48.4 percent, respectively over $100 \%$ NPK application alone. Nutrient efficiency ratio and physiological efficiencies of $\mathrm{N}, \mathrm{P}$ and $\mathrm{K}$ were higher in the treatments having the alone application of bio/vermicompost and trends in efficiency ratio and physiological efficiencies of $\mathrm{N}, \mathrm{P}$ and $\mathrm{K}$ were found just reverse to the trends of N, P and K uptakes. Dehydrogenase activity was found maximum with the treatment bio-compost @ $10 \mathrm{t} \mathrm{ha}^{-1}$ alone which decreased with the application of fertilizers, vermicompost, FYM and their combination with $100 \%$ NPK. The organic carbon, total nitrogen were significantly higher in treatments of biocompost alone application in comparison to control followed by biocompost treatments applied in combination with 100\% NPK. Organic carbon, total nitrogen and total phosphorus and microbial population and biomass, dehydrogenase activity was significantly higher in biocompost in comparison to vermicompost with same level of application and in combination with100\% NPK. Being maximum in alone biocompost application, decrease in bacterial population was noticed to the tune of 21 percent in the treatments-vermicompost @10 t with the inorganic fertilizer and in sole application of NPK fertilizer over vermicompost application alone. Maximum population of actinomycetes was in the treatments where vermicompost and biocompost was applied alone. All the soil microbiological properties were significantly higher in biocompost than vermicompost application except the actinomycetes population where it was higher in vermicompost. Microbial population showed significant and positive correlation with the organic carbon, biomass carbon, total nitrogen and total phosphorus of the rhizosheric soil. Dehydrogenase activity has positive and significant correlation with microbial population but it was not significant with total phosphorus and total nitrogen. Dehydrogenase activity did show positive and significant correlation with microbial biomass carbon. 


\section{Introduction}

Plant growth under field conditions is one of the most complex interactive amongst physical, chemical, and biological systems. Crop yield is a function of soil, crop, climate and management factors. Amongst these factors, soil has edge over all others. Soil fertility and soil health consist of physical, chemical and biological components and their interaction. Hitherto, the major emphasis on soil fertility and soil health, investigation has been carried out on the basis of physical and chemical attributes of soil to define soil productivity, soil quality vis a vis soil health (Arshad and Coen 1992). The biological component has been largely ignored, though are an important aspect to manage sustainable agriculture, soil health and ecosystem. The biological component of soil is responsible for humus formation, cycling of nutrients, soil tilth and structure and myriad of other functions (Tisdall, 1991). Thus, it is essential to maintain the physical, chemical and biological components of soil for sustainable agriculture. The maintenance of all these factors together is essentially required with the use of organic inorganic and integration of organic and inorganic and biofertilizers together for restoration of declining soil productivity. None of single source of mineral/chemical fertilizers, organic/crop residue and bio-fertilizer alone can produce required food to nourish the bourgeoning human population (Gaur, 1998). The combined use of organic manures and inorganic fertilizers influences the soil health and plays an important role in energy flow and nutrient cycling. Fortunately the potential of manorial resources is high in India (Ramaswami 1999). Composting as emerged as essential technology and have high potential for conversion of weedy plants like Lantana, Eupatorium and Parthenium as manure in humid hills of Himalayas (Sharma et al., 2004).
Okra fruits are very nutritious and contain vitamin $\mathrm{C}$ and minerals like calcium, magnesium, sodium and iron. The consumption of $100 \mathrm{~g}$ of fresh okra fruits provide $20 \%, 15 \%$ and $50 \%$ of the needs of calcium, iron and ascorbic acid (Hamon, 1988). Being nutritious crop, the requirement of nutrients for okra is very high and farmers have to apply more and more amount of imbalanced chemical fertilizers year after year to get high remunerative price of this commercial crop. Application of more and more amount of imbalanced chemical fertilizers year after year is neither economical to farmers nor judicious to soil productivity and soil health. Therefore, present study was formulated to compare the organic, inorganic alone and their integration on yield, nutrient uptake and protein and mineral content of okra and microbiological properties of the rhizospheric soil.

\section{Materials and Methods}

\section{Basic soil properties and treatment details}

Bio-compost and vermicompost and Farmyard manure (FYM) were prepared by using cowdung and weed plant Lantana camera harvested in the month of September before the formation of fruits. The biocompost and vermicompost were prepared by mixing cow dung and Lantana in the ratio of 1:1 by heap method. The bio-compost and FYM were ready in four and half months and vermicompost took 70 days for maturity. These manures and compost were prepared with the inoculation of Azotobacter chroococcum culture added after 15 days in case of vermicompost and after one month in case of bio-compost and FYM. A field experiment was conducted with 11 treatments and three replications in randomized block design on Okra during the year 2005 at the research farm of Department of Soil Science, Chaudhary Sarvan Kumar Himachal Pradesh 
Krishi Vishvavidyalaya, Palampur $\left(32^{\circ} 6^{\prime}\right.$ N,76 ${ }^{\circ}$ ' E, $1300 \mathrm{~m}$ amsl), Himachal Pradesh, India. The details of treatments were: $T_{1}$ control, $\mathrm{T}_{2^{-}} \quad$ biocompost@5 $\mathrm{t} \quad \mathrm{ha}^{-1}, \quad \mathrm{~T}_{3^{-}}$ vermicompost@5 t ha ${ }^{-1}, \mathrm{~T}_{4}$ - biocompost@10 t ha ${ }^{-1}, \mathrm{~T}_{5}$ - vermicompost @10 t ha ${ }^{-1}, \mathrm{~T}_{6}-\mathrm{N}$ $75, \mathrm{P}_{2} \mathrm{O}_{5}$ and $50 \mathrm{~K}_{2} \mathrm{O} 50 \mathrm{~kg} \mathrm{ha}{ }^{-1}, \mathrm{~T}_{7}-\mathrm{T}_{6}+$ biocompost@5 t ha ${ }^{-1}, \mathrm{~T}_{8}-\mathrm{T}_{6}+$ biocompost @10 t ha ${ }^{-1}, \mathrm{~T}_{9}-\mathrm{T}_{6}+$ vermicompost @ $5 \mathrm{t} \mathrm{ha}^{-1}$ $\mathrm{T}_{10-} \mathrm{T}_{6}+$ vermicompost @10t ha ${ }^{-1}, \mathrm{~T}_{11}-100 \%$ $\mathrm{NPK}+$ farmyard manure @10 t ha ${ }^{-1}$. Nitrogen, phosphorus and potassium were added through IFFCO (12:32:16) mixture as basal and nitrogen through urea in three equal splits, one as basal and $2^{\text {nd }}$ and third after one and two months of sowing. The soil (typic Hapludalf) was silty clay loam in texture. The soil have $\mathrm{pH} 5.6$ (1:2.5 soil to water),organic carbon $7.8 \mathrm{~g} \mathrm{~kg}^{-1}$,cation exchange capacity $12.0 \mathrm{cmol}\left(\mathrm{p}^{+}\right) \mathrm{kg}^{-1}$, available nitrogen phosphorus and potassium were 482, 9.0 and $263 \mathrm{~kg} \mathrm{ha}^{-1}$.

The bio-compost, vermicompost and farmyard manure contained 1.51, 1.73 and $0.56 \% \mathrm{~N}, 0.42,0.83$ and $0.17 \% \mathrm{P}$ and 0.56 , 0.28 and $0.52 \% \mathrm{~K}, 1.1,1.2$ and $0.7 \% \mathrm{Ca}$, $0.50,0.62,0.0 .37 \% \mathrm{Mg}, 0.25,0.30,0.24 \% \mathrm{Fe}$ respectively. Crop variety $\mathrm{P}-8$ was sown in 10 $\mathrm{m}^{2}$ plots on $28^{\text {th }}$ of June, 2005 by following recommended packages of practices for vegetable crops.

\section{Soil and plant sampling and analysis}

The green fruits of 7-9 days of growth of four pickings were mixed, dried and analyzed for mineral nitrogen $(\mathrm{N})$, phosphorus $(\mathrm{P})$, potassium $(\mathrm{K})$, calcium $(\mathrm{Ca})$, magnesium $(\mathrm{Mg})$ and iron $(\mathrm{Fe})$ contents by wet digestion method. The nitrogen of fruits and stalk and manures and composts and FYM was analyzed by nitrogen auto analyzer, $\mathrm{P}$ was measured by the phosphovanadomolybdate method, $\mathrm{K}$ by flame photometry and $\mathrm{Ca}$ and $\mathrm{Mg}$ and $\mathrm{Fe}$ by atomic absorption spectrophotometry. The data on fruit, and dry matter yield were estimated by summing all the fruits harvested in different picking from each plot.

Nitrogen/phosphorus/potassium efficiency ratio=

$\frac{\text { Dry-matter yield at harvest }\left(\mathrm{kg} \mathrm{ha}^{-1)}\right.}{\mathrm{N} / \mathrm{P} / \mathrm{K} \text { accumulation in crop at harvest }\left(\mathrm{kgha}^{-1}\right)}$

Physiological efficiency index of absorbed nitrogen/phosphorus/potassium were calculated as ratio of $\mathrm{kg}$ fruit produced to a $\mathrm{kg}$ of nitrogen or phosphorus or potassium absorbed in above ground dry matter yield. The rhizospheric soil samples at harvest were drawn for the estimation of dehydrogenase activity, microbial count and biomass carbon, population of nitrogen fixer-Azotobacter, organic carbon, total nitrogen and total phosphorus. The microbial count for bacterial, fungal and actinomycetes of soil samples was determined using standard methods. Isolation of viable microbial count was done by the serial dilution technique on Jenson's medium (A. chroococcum).Ten grams of soil from each sample were drawn and serially diluted aseptically to $10^{-4}, 10^{-5}$ and $10^{-6}$ dilution. One $\mathrm{ml}$ of each sample dilution was spread on the specified medium.

Colony forming units were determined on agar plates (three replications per dilution) incubated at $30^{\circ} \mathrm{C}$ for one week.

A soil-extract agar medium (Bunt and Rovira 1955) was used for bacteria, inorganic starch medium for actinomycetes and rose Bengal streptomycin agar (Martin 1950) was used to count fungi. The microbial biomass was estimated as biomass carbon by the chloroform-fumigation technique described by Jenkinson and Powlson (1976). Dehydrogenase activity was assayed according to Casida et al., (1964).The soil samples were incubated at $37^{\circ} \mathrm{C}$ for 24 hour 
(h) and activity was assessed as triphenylformazan produced over $24 \mathrm{~h}$ and expressed on hour basis.

\section{Statistical analysis}

The experiment was laid out in a randomized block design according to Gomez and Gomez (1984). Statistical analysis of the data was carried out using a one way analysis of variance (ANOVA) to compare the efficiency of bio and vermicompost sources of nutrients. The significance of variation among the treatments was observed by applying the Ftest, and thus critical difference was calculated at the 5\% level of probability.

\section{Results and Discussion}

\section{Plant height and fruit and stalk yield}

The plant height and number of fruit per plant are the yield attributing characters of the crop. The maximum plant height was recorded with the application of farmyard manure in combination with 100 percent NPK followed by 100 percent NPK + vermicompost @10 t ha $^{-1}$ which is 45.8 and 22.8 percent higher than 100 percent NPK application alone (Table 1). The application of urea produced higher plant height than application of bio/vermicompost alone. This might be due to inability of organic nitrogen source to release the nutrients at peak requirement of crop. The combined application of inorganic and organic manure produced higher plant height. Similar results were recorded in rice by Singh et al., (2005), in groundnut and finger millet by Varalakshmi et al., (2005). There was 65.0 and $46.9 ; 245$ and 235 percent increase in fruit yield with the application of vermicompost in combination with $100 \%$ NPK in comparison to $100 \%$ NPK alone and control respectively. Almost similar results were obtained with biocompost @ $10 \mathrm{t} \mathrm{ha}^{-1}$ along with $100 \%$ NPK application. Each bio- compost and vermicompost@ $5 \mathrm{t}$ along with $100 \%$ NPK gave equivalent yield to $100 \%$ NPK+10 t FYM ha ${ }^{-1}$. This is due the fact that the N-containing organic compounds in FYM are much more resistant to decomposition than bio/vermicompost, and only one third is easily released. It is also emphasized that $\mathrm{P}$ present in organic manure and half of the total $\mathrm{P}$ present quickly become available to crops. In contrast, $\mathrm{K}$ is almost totally water soluble as $\mathrm{K}^{+}$ions and is readily available to the plant (Sharma et al., 2011). It is evident that the quantity of farmyard manure can be reduced to half with the use of either vermicompost or biocompost.

\section{Mineral nutrient contents}

Application of inorganic fertilizers either alone or in combination with bio/vermicomost @ $10 \mathrm{t} \mathrm{ha}^{-1}$ and FYM@ $10 \mathrm{tha}^{-1}$ increased the $\mathrm{N}, \mathrm{P} \mathrm{K}, \mathrm{Ca}, \mathrm{Mg}$ and iron contents both in fruit as well as in stalk over the control (Table 2 4) The nitrogen content ranged between 3.05 to $4.25 \%$ in fruit and 3.20 to $4.03 \%$ in stalk, phosphorus ranged between 0.40 to $0.61 \%$ in fruit and 0.35 to $0.51 \%$ in stalk, potassium from 1.45 to $2.29 \%$ in fruit and 3.4 to $5.2 \%$ in stalk. Calcium contents in fruit range between 0.34 to 0.56 , magnesium from 1.10 to $1.25 \%$ and iron from 21 to $48 \mathrm{mg} \mathrm{kg}^{-1}$. The mineral contents were significantly increased with the combined use of biocompost/vermicompost with $100 \%$ NPK than the alone application of either biocompost/vermicompost or $100 \%$ NPK. The protein content ranged between 19.0 to $26.3 \%$. The mineral contents followed the results of Swain et al., 2003 except for calcium where the values found under this experiment were lower. Maximum mineral contents were found in $100 \%$ $\mathrm{NPK}+10 \mathrm{t} \mathrm{ha}^{-1}$ vermicompost which was at par with 100\% NPK+ biocompost @ $10 \mathrm{t} \mathrm{ha}^{-1}$ and $100 \% \mathrm{NPK}+\mathrm{FYM} 10 \mathrm{t} \mathrm{ha}^{-1}$ and lowest in the control The treatments100\% NPK+@5 t $\mathrm{ha}^{-1}$ either vermicompost or biocompost 
proved equally effective in influencing contents of $\mathrm{N}, \mathrm{P} \mathrm{K}$ and other mineral contents in the fruit and stalk. The higher N, P, K, Ca, $\mathrm{Mg}$ and $\mathrm{Fe}$ contents in these treatments may be attributed to better supply of nutrients through bio/vermicomposts. This corroborates the findings of Sreenivas et al., (2000) about N, P and K and results of Agbo et al., (2008) about protein and the other mineral contents.

\section{Nutrient uptake}

Nitrogen uptake in fruit and stalk was maximum i.e.55.4 and $70.6 \mathrm{~kg} \mathrm{ha}^{-1}$ with the application of vermicompost @10 $\mathrm{t} \mathrm{ha}^{-1}$ in combination with $100 \%$ NPK. The increase in nitrogen uptake both in fruit and stalk was 67.7 and 48.4 percent, respectively over NPK application alone. This is due to increased availability of nutrients following combined use of enriched vermicompost/biocompost and fertilizer that might have enhanced the nutrient uptake. The corresponding increase in phosphorus uptake was 71.3 and 65.4 percent with enriched vermicompost @10 t $\mathrm{ha}^{-1}$ in combination with $100 \%$ NPK over $100 \%$ NPK alone. The results corroborate the findings of Kale et al., (1992) who reported that the availability and uptake of nitrogen and phosphorus were more in vermicompost treated plot as compared to FYM treated plot. The increase in K uptake was 78.7 and 50.0 percent of these treatments over $100 \%$ NPK alone. The total $\mathrm{N}, \mathrm{P}$ and $\mathrm{K}$ uptakes were increased significantly with the application of biocompost/vermicompost over the control. It might be due to the synergistic effect of compost /FYM which on decomposition released macro and micronutrients, less fixation of applied phosphorus, thereby increasing the availability of nutrients in soil and uptake by plant. Similar findings were reported by Minhas and Sood, 1994 and Rathore et al., 1995.

Table.1 Effect of organic, inorganic and integrated source of nutrients on yield attributes and yield of okra

\begin{tabular}{|c|c|c|c|c|c|}
\hline Treatments & $\begin{array}{l}\text { No. of Fruits } \\
\text { plant }^{-1}\end{array}$ & $\begin{array}{l}\text { Plant height } \\
\text { (m) }\end{array}$ & $\begin{array}{c}\text { Fruit yield( } t \\
\left.\mathbf{h a}^{-1}\right)\end{array}$ & $\begin{array}{l}\text { Dry fruit } \\
\text { yield }\left(\mathrm{tha}^{-1}\right)\end{array}$ & $\begin{array}{c}\text { Dry stalk } \\
\text { yield }\left(\mathrm{t} \mathrm{ha}^{-1}\right)\end{array}$ \\
\hline$T_{1}$ & 6 & 0.73 & 2.91 & 0.34 & 0.63 \\
\hline $\mathbf{T}_{2}$ & 10 & 1.04 & 4.46 & 0.52 & 1.32 \\
\hline $\mathbf{T}_{3}$ & 9 & 1.04 & 4.96 & 0.57 & 1.30 \\
\hline $\mathbf{T}_{4}$ & 9 & 1.09 & 5.47 & 0.63 & 1.06 \\
\hline $\mathbf{T}_{5}$ & 10 & 1.20 & 6.03 & 0.79 & 1.83 \\
\hline$T_{6}$ & 9 & 1.01 & 6.07 & 0.70 & 1.01 \\
\hline $\mathbf{T}_{7}$ & 9 & 1.10 & 7.63 & 0.88 & 1.52 \\
\hline $\mathbf{T}_{8}$ & 9 & 1.14 & 9.37 & 1.09 & 1.68 \\
\hline $\mathbf{T}_{9}$ & 10 & 1.24 & 7.54 & 0.87 & 1.51 \\
\hline $\mathbf{T}_{10}$ & 9 & 9.80 & 10.06 & 1.17 & 1.47 \\
\hline $\mathbf{T}_{11}$ & 12 & 1.47 & 8.10 & 0.94 & 1.85 \\
\hline LSD $_{0.05}$ & NS & 0.245 & 1.25 & 0.145 & NS \\
\hline
\end{tabular}

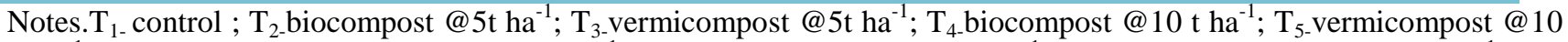
t ha ${ }^{-1} ; \mathrm{T}_{6^{-}} \mathrm{N}-75, \mathrm{P}_{2} \mathrm{O}_{5}-50, \mathrm{~K}_{2} \mathrm{O}-50 \mathrm{~kg} \mathrm{ha}{ }^{-1} ; \mathrm{T}_{7-} \mathrm{T}_{6}+$ biocompost @5t ha ${ }^{-1} ; \mathrm{T}_{8-} \mathrm{T}_{6}+$ biocompost @10 t ha ${ }^{-1} ; \mathrm{T}_{9-}$ $\mathrm{T}_{6}+$ vermicompost@5tha ${ }^{-1} ; \mathrm{T}_{10-} \mathrm{T}_{6}+$ vermicompost@10tha ${ }^{-1} ; \mathrm{T}_{11}-\mathrm{T}_{6}+\mathrm{FYM} @ 10$ tha ${ }^{-1} ; \mathrm{NS}=$ Means with a column are not statistically different at $5 \%$ level 
Table.2 Effect of organic, inorganic and integrated source of nutrients on nutrient concentration (\%) and uptake (kg ha $\left.{ }^{-1}\right)$ by fruit and stalk of okra

\begin{tabular}{|c|c|c|c|c|c|c|c|c|c|c|c|c|c|c|c|}
\hline \multirow{3}{*}{$\begin{array}{l}\text { Treatments } \\
\mathbf{T}_{1}\end{array}$} & \multicolumn{5}{|c|}{$\mathrm{N}$ concentration and uptake } & \multicolumn{5}{|c|}{$P$ concentration and uptake } & \multicolumn{5}{|c|}{$K$ concentration and uptake } \\
\hline & \multicolumn{5}{|c|}{ Fruit Stalk Fruit Stalk Total } & \multicolumn{5}{|c|}{ Fruit Stalk Fruit Stalk Total } & \multicolumn{5}{|c|}{ Fruit Stalk Fruit Stalk To } \\
\hline & 3.05 & 3.20 & 10.4 & 16.9 & 27.3 & 0.40 & 0.35 & 1.4 & 1.8 & 3.2 & 1.45 & 3.4 & 5.2 & 18.2 & 23.4 \\
\hline $\mathbf{T}_{2}$ & 4.15 & 3.88 & 21.6 & 19.8 & 41.4 & 0.54 & 0.40 & 2.8 & 3.2 & 6.0 & 1.90 & 4.2 & 9.8 & 14.0 & 23.8 \\
\hline $\mathbf{T}_{3}$ & 4.16 & 3.89 & 23.7 & 32.7 & 56.4 & 0.54 & 0.42 & 3.1 & 3.5 & 6.6 & 1.91 & 4.3 & 11.0 & 36.1 & 47.1 \\
\hline $\mathbf{T}_{4}$ & 4.18 & 3.91 & 26.3 & 41.4 & 67.7 & 0.58 & 0.44 & 3.7 & 4.7 & 8.3 & 2.05 & 4.5 & 13.0 & 47.6 & 60.6 \\
\hline$T_{5}$ & 4.18 & 3.91 & 33.0 & 42.6 & 75.6 & 0.58 & 0.45 & 4.1 & 4.9 & 9.0 & 2.06 & 4.6 & 14.4 & 50.1 & 54.5 \\
\hline$T_{6}$ & 4.19 & 3.92 & 29.3 & 47.6 & 76.9 & 0.59 & 0.46 & 4.2 & 5.6 & 9.7 & 2.15 & 4.7 & 15.2 & 57.0 & 72.2 \\
\hline $\mathbf{T}_{7}$ & 4.21 & 3.95 & 37.0 & 60.2 & 107.2 & 0.60 & 0.51 & 5.3 & 7.8 & 13.1 & 2.24 & 5.0 & 19.8 & 76.2 & 96.4 \\
\hline $\mathbf{T}_{8}$ & 4.24 & 3.93 & 46.2 & 68.7 & 114.9 & 0.61 & 0.52 & 6.7 & 9.1 & 15.8 & 2.30 & 5.2 & 25.0 & 90.7 & 115.7 \\
\hline $\mathbf{T}_{9}$ & 4.22 & 3.95 & 36.7 & 62.9 & 99.6 & 0.60 & 0.50 & 5.3 & 7.9 & 13.2 & 2.25 & 4.9 & 19.7 & 77.8 & 97.5 \\
\hline$T_{10}$ & 4.25 & 3.98 & 49.7 & 70.6 & 120.3 & 0.61 & 0.52 & 7.1 & 9.2 & 16.3 & 2.32 & 5.1 & 27.1 & 90.4 & 117.5 \\
\hline$T_{11}$ & 4.20 & 4.03 & 39.5 & 65.7 & 105.2 & 0.61 & 0.51 & 5.6 & 8.3 & 13.9 & 2.29 & 4.8 & 21.5 & 78.4 & 99.9 \\
\hline $\operatorname{LSD}_{0.05}$ & 0.50 & 0.45 & 4.39 & 18.38 & 20.41 & 0.07 & 0.06 & 0.54 & 1.65 & 2.02 & 0.31 & 0.87 & 2.67 & 12.36 & 13.38 \\
\hline
\end{tabular}

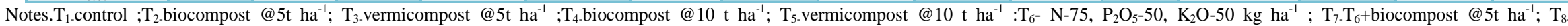

$\mathrm{T}_{6}+$ biocompost @ $10 \mathrm{tha}^{-1} ; \mathrm{T}_{9 .} \mathrm{T}_{6}+$ vermicompost $@ 5$ tha $^{-1} ; \mathrm{T}_{10} \mathrm{~T}_{6}+$ vermicompost@10tha ${ }^{-1} ; \mathrm{T}_{11}-\mathrm{T}_{6}+\mathrm{FYM} @ 10$ tha ${ }^{-1}$

Table.3 Effect of organic, inorganic and integrated source of nutrients on quality of okra fruits

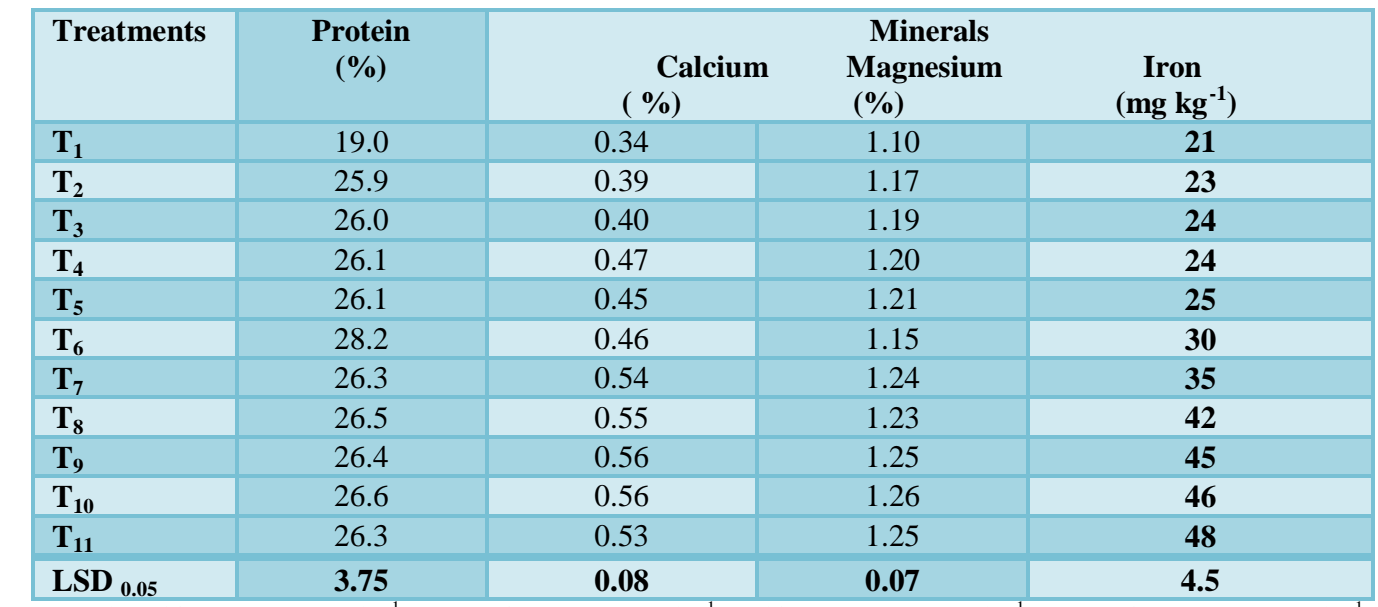

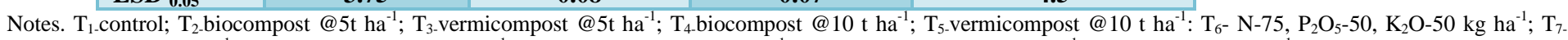

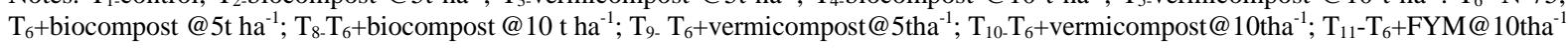


Table.4 Effect of organic, inorganic and integrated source of nutrients on nutrient (N/P/K) efficiency ratio and physiological efficiency index (PEI of N/P/K) of okra

\begin{tabular}{|l|l|l|l|l|l|l|}
\hline Treatment & \multicolumn{3}{|c|}{ N/P/K efficiency ratio } & \multicolumn{3}{c|}{ Physiological efficiency index } \\
& NER & PER & KER & PEIN & PEIP & PEIK \\
\hline $\mathbf{T}_{\mathbf{1}}$ & 355.3 & 3031.2 & 414.5 & 124.5 & 1062.5 & $\mathbf{1 4 5 . 3}$ \\
\hline $\mathbf{T}_{\mathbf{2}}$ & 444.4 & 3066.6 & 773.1 & 125.6 & 866.6 & $\mathbf{2 1 8 . 5}$ \\
\hline $\mathbf{T}_{\mathbf{3}}$ & 331.6 & 2833.0 & 397.0 & 101.0 & 863.6 & $\mathbf{1 2 1 . 0}$ \\
\hline $\mathbf{T}_{\mathbf{4}}$ & 249.6 & 2036.0 & 278.8 & 93.1 & 759.0 & $\mathbf{1 0 3 . 9}$ \\
\hline $\mathbf{T}_{\mathbf{5}}$ & 346.5 & 2911.0 & 480.7 & 104.5 & 877.7 & $\mathbf{1 4 4 . 9}$ \\
\hline $\mathbf{T}_{\mathbf{6}}$ & 222.3 & 1762.8 & 238.8 & 91.0 & 721.6 & $\mathbf{9 6 . 9}$ \\
\hline $\mathbf{T}_{\mathbf{7}}$ & 223.9 & 1846.1 & 248.9 & 82.1 & 676.9 & $\mathbf{9 1 . 3}$ \\
\hline $\mathbf{T}_{\mathbf{8}}$ & 241.1 & 1753.1 & 239.4 & 94.9 & 689.8 & $\mathbf{9 4 . 2}$ \\
\hline $\mathbf{T}_{\mathbf{9}}$ & 238.9 & 1803.0 & 244.1 & 87.3 & 659.1 & $\mathbf{8 9 . 2}$ \\
\hline $\mathbf{T}_{\mathbf{1 0}}$ & 219.5 & 1619.6 & 224.6 & 97.3 & 717.8 & $\mathbf{9 9 . 6}$ \\
\hline $\mathbf{T}_{\mathbf{1 1}}$ & 265.2 & 2007.1 & 279.2 & 89.4 & 676.2 & $\mathbf{9 4 . 1}$ \\
\hline $\mathbf{L S D}_{\mathbf{0 . 0 5}}$ & $\mathbf{3 8 . 3 6}$ & $\mathbf{8 8 . 6 9}$ & $\mathbf{3 3 . 6 7}$ & $\mathbf{8 . 7 1}$ & $\mathbf{4 8 . 5 2}$ & $\mathbf{1 3 . 6 9}$ \\
\hline
\end{tabular}

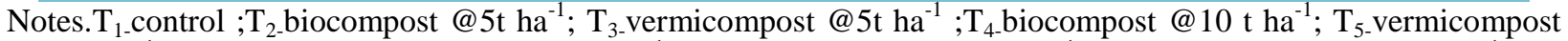
$@ 10 \mathrm{t} \mathrm{ha}{ }^{-1}: \mathrm{T}_{6^{-}} \mathrm{N}-75, \mathrm{P}_{2} \mathrm{O}_{5}-50, \mathrm{~K}_{2} \mathrm{O}-50 \mathrm{~kg} \mathrm{ha}{ }^{-1} ; \mathrm{T}_{7-} \mathrm{T}_{6}+$ biocompost @ $5 \mathrm{t} \mathrm{ha}^{-1} ; \mathrm{T}_{8-} \mathrm{T}_{6}+$ biocompost @ $10 \mathrm{t} \mathrm{ha}^{-1} ; \mathrm{T}_{9}$ $\mathrm{T}_{6}+$ vermicompost $@ 5$ tha $^{-1} ; \mathrm{T}_{10}-\mathrm{T}_{6}+$ vermicompost@10tha ${ }^{-1} ; \mathrm{T}_{11}-\mathrm{T}_{6}+\mathrm{FYM} @ 10$ tha $^{-1}$

NER, PER, KER - nitrogen, phosphorus and potassium efficiency ratio; PEIN, PEIP, PEIK - Physiological efficiency index of nitrogen, phosphorus and potassium

Table.5 Effect of organic, inorganic and integrated source of nutrients on chemical and microbiological properties of soil

\begin{tabular}{|c|c|c|c|c|c|c|c|c|c|}
\hline \multirow[t]{2}{*}{ Treatments } & \multirow{2}{*}{$\begin{array}{c}\text { Dehydrogen } \\
\text { ase activity } \\
\left({ }^{\mathbf{u g T P F} \mathrm{g}^{-}}\right. \\
\left.{ }^{1} \mathbf{h r}^{-1}\right)\end{array}$} & \multirow{2}{*}{$\begin{array}{c}\text { Microbial } \\
\text { biomass } \\
\text { carbon( }(\mu \mathrm{g} \\
\left.\mathrm{C} \mathrm{g}^{-1} \text { soil }\right)\end{array}$} & \multirow{2}{*}{$\begin{array}{c}\text { Total } \\
\text { nitrogen } \\
\left(\mathrm{kg} \mathrm{ha}^{-1}\right)\end{array}$} & \multirow{2}{*}{$\begin{array}{c}\text { Total } \\
\text { phospho } \\
\text { rus } \\
\left(\mathrm{kg} \mathrm{ha}^{-1}\right)\end{array}$} & \multirow{2}{*}{$\begin{array}{c}\text { Organic } \\
\text { carbon } \\
\left(\mathrm{g} \mathrm{kg}^{-1}\right)\end{array}$} & \multicolumn{4}{|c|}{ Microbial population(cfu $\left.\mathrm{g}^{-1}\right)$} \\
\hline & & & & & & $\begin{array}{l}\text { Bacterial } \\
\left(\mathbf{x 1 0}^{6}\right)\end{array}$ & $\begin{array}{l}\text { Fungal } \\
\left(\mathbf{x 1 0}^{5}\right)\end{array}$ & $\begin{array}{l}\text { Actinom } \\
\left(\times 10^{4}\right)\end{array}$ & $\begin{array}{l}\text { zotobacter } \\
\qquad\left(\mathbf{x 1 0}^{3}\right)\end{array}$ \\
\hline $\mathbf{T}_{1}$ & 3.8 & 132 & 2096 & 882 & 7.9 & 49.6 & 12 & 16 & 12.3 \\
\hline $\mathbf{T}_{2}$ & 5.0 & 167 & 2168 & 891 & 8.5 & 76.6 & 17 & 22 & 20.0 \\
\hline $\mathbf{T}_{3}$ & 4.5 & 158 & 2170 & 898 & 8.6 & 71.3 & 13.6 & 20 & 19.0 \\
\hline $\mathbf{T}_{4}$ & 5.4 & 217 & 2163 & 927 & 8.0 & 86.0 & 29.6 & 27 & 33.0 \\
\hline $\mathbf{T}_{5}$ & 5.2 & 192 & 2165 & 906 & 8.0 & 74.6 & 14.0 & 30 & 15.0 \\
\hline $\mathbf{T}_{6}$ & 4.5 & 157 & 2120 & 902 & 8.1 & 59.6 & 12.0 & 19 & 9.0 \\
\hline $\mathbf{T}_{7}$ & 4.6 & 173 & 2158 & 904 & 8.3 & 69.6 & 20.0 & 20 & 10.0 \\
\hline $\mathbf{T}_{8}$ & 4.9 & 205 & 2168 & 912 & 8.5 & 72.0 & 21.6 & 25 & 11.0 \\
\hline $\mathbf{T}_{9}$ & 4.7 & 163 & 2124 & 902 & 8.0 & 57.6 & 12.6 & 19 & 9.0 \\
\hline$T_{10}$ & 4.8 & 184 & 2128 & 910 & 8.0 & 59.3 & 13.6 & 22 & 10.0 \\
\hline$T_{11}$ & 5.2 & 190 & 2136 & 914 & 8.1 & 58.3 & 18.0 & 21 & 18.0 \\
\hline LSD $_{0.05}$ & 0.8 & 43.8 & 32.0 & NS & 0.5 & 2.5 & 2.7 & 2.6 & 3.6 \\
\hline Initial soil & 3.9 & 148 & 2088 & 880 & 7.8 & 48.0 & 11.6 & 17 & 9.0 \\
\hline
\end{tabular}


Table.6 Correlation between microbiological properties and some chemical properties

\begin{tabular}{|l|c|c|c|c|c|c|c|c|}
\hline \multicolumn{1}{|c|}{ Soil property } & $\begin{array}{c}\text { Fungal } \\
\text { Populati } \\
\text { on }\end{array}$ & $\begin{array}{c}\text { Azotoba } \\
\text { cter }\end{array}$ & $\begin{array}{c}\text { Actinomycetes } \\
\text { Population }\end{array}$ & $\begin{array}{c}\text { Microbial } \\
\text { biomass } \\
\text { C }\end{array}$ & $\begin{array}{c}\text { Dehydrog } \\
\text { enase } \\
\text { activity }\end{array}$ & O.C & Total N & Total P \\
\hline Bacterial population & $0.70^{* *}$ & $0.62^{* *}$ & $0.71^{* *}$ & $0.49^{* *}$ & $0.36^{*}$ & $0.50^{* *}$ & $0.43^{* *}$ & $\mathbf{0 . 5 3 * *}$ \\
\hline Fungal population & & $0.70^{* *}$ & 0.27 & $0.58^{* *}$ & $0.36^{*}$ & $0.58^{* *}$ & $0.66^{* *}$ & $\mathbf{0 . 6 5} * *$ \\
\hline Azotobacter population & & & $0.34^{*}$ & $0.60^{* *}$ & 0.23 & $0.62^{* *}$ & $0.67^{* *}$ & $\mathbf{0 . 7 3} * *$ \\
\hline Actinomycetes population & & & & $0.62^{* *}$ & 0.29 & $0.38^{*}$ & $0.49^{* *}$ & $\mathbf{0 . 6 5} * *$ \\
\hline Microbial biomass C & & & & & $0.57^{* *}$ & $0.72^{* *}$ & $0.61^{* *}$ & $\mathbf{0 . 4 7} * *$ \\
\hline Dehydrogenase activity & & & & & & $0.37^{*}$ & 0.19 & $\mathbf{0 . 2 9}$ \\
\hline O.C & & & & & & $0.57^{* *}$ & $\mathbf{0 . 5 3 * *}$ \\
\hline Total N & & & & & & & $\mathbf{0 . 4 8 * *}$ \\
\hline
\end{tabular}

*, **-relationship significant at $\mathrm{p}<0.05,<0.01$, respectively; O.C.-organic carbon, $\mathrm{N}$-nitrogen, P-phosphorus

Nutrient efficiency ratio and physiological efficiency

Nutrient efficiency ratio and physiological efficiencies of $\mathrm{N}, \mathrm{P}$ and $\mathrm{K}$ were higher in the treatments having the alone application of vermi/biocompost (Table 4). The trends were reverse to the trends found in terms of respective uptake for nitrogen, phosphorus and potassium. This is possible because the efficiency of nutrients is maximum in organic treatment than inorganic fertilizers alone as the losses of nutrients are more in inorganic fertilizers. The findings support the results of Rana et al., 2006 who reported that the organic treatments have better efficiencies and physiological efficiencies than inorganic treatments.

\section{Effect of bio/vermicompost, FYM and NPK and their combination on microbiological and some chemical properties of soil}

\section{Microbial population}

\section{Bacteria}

Bacterial population in soil showed significantly more abundance than rest of the treatments where biocompost was applied alone followed by vermicompost alone, biocompost $+100 \%$ NPK, vermicompost $+100 \%$ NPK, $100 \%$ NPK alone and least in the control. There is decrease in number with application of inorganic fertilizer in combination with compost and FYM than their sole application. These results are in agreement with the findings of Kamlesh et al., (1991) who noticed that population of bacteria is favoured by the application of composts alone. Decrease in bacterial population was noticed to the tune of 21 percent in each case in the treatments-vermicompost @ $10 \mathrm{t}$ in combination with the inorganic fertilizer and in sole application of NPK fertilizer over vermicompost application alone.

\section{Azotobacter}

The population of free living Azotobacter remained similar to bacterial population. Their number was found more where biocompost has been applied even in the plots where no manuring and fertilization was done i.e. control in comparison to $100 \%$ NPK + vermicompost@5 tonnes $\mathrm{ha}^{-1}$. In the sole application of vermicompost @ $10 \mathrm{tha}^{-1}$ their population was $15 \times 10^{3} \mathrm{cfu}^{-1}$ soil which reduces to $10 \times 10^{3} \mathrm{cfu}$ with the application of NPK fertilizer along with vermicompost. The reduction is 18 percent in comparison to where no manuring and fertilization has been made. The results are in pattern to the data of organic carbon in the Table 5. Similar finding has been reported by Mishutin and Shilnikova (1971). They reported that Azotobacter 
population increases with increase in organic carbon content. Results also corroborate the finding of Swain et al., 2003 who reported increase in the population of Azotobacter at the okra harvest with the application of inorganic fertilizers and bioinoculants. Amongst the different combinations of composts and FYM @10 t ha ${ }^{-1}$ with 100\% NPK, farm yard manure has higher population in comparison to bio and vermicompost. This is expected as the FYM being stable manure that might decompose slowly than the other bio and vermicompost. Similar observation has been made by Rita et al., (1998) who found that population of bacteria was favoured by the application of FYM+100\% NPK and FYM alone.

\section{Fungi}

Their number decreased significantly with the application of NPK fertilizer and combined application of compost with inorganic fertilizers. There was 27 percent decrease in number in $100 \%$ NPK + bio-compost @10 t $\mathrm{ha}^{-1}$ than alone application of biocompost. It may be due to change in the reaction as results of acceleration in decomposition with the addition of NPK fertilizers.

\section{Actinomycetes}

Actinomycetes are major source of antibiotic used for disease control and some also fix dinitrogen to usable form. Maximum population of actinomycetes was in the treatments vermicompost @ $10 \mathrm{t} \mathrm{ha}^{-1}$ followed by bio-compost at the same rate when each applied alone. The population of these two treatments significantly differed with rest of the treatments except the treatment BC@10 t $\mathrm{ha}^{-1}$ in combination with $100 \%$ NPK.The reduction in number is $26.6,36.6$ and 10.0 percent when vermicompost applied with $100 \%$ NPK, $100 \%$ NPK alone and biocompost @10 t ha ${ }^{-1}$ respectively in comparison to vermicompost @10 t ha applications. In their findings Sharma et al., (1983) stated that the bacteria and actinomycetes favoured soil $\mathrm{pH}$ above 6.0 that is suitable in vermicompost. Similar findings have been given by Rita et al., (1998).The fungal and actinomycetes in general increase in the treatments where biocompost/vermicompost was applied alone or in combination with $100 \%$ NPK. This is expected since these microorganisms are chemoheterotrophs, which require organic carbon as food and oxidation of organic substances provide energy which might be available more in bio/vermicompost alone treatments and secondly due to the fact that fungal and actinomycetes show their activity at the later stages of decomposition on resistant components. It is evident from the Table 5 that maximum dehydrogenase activity was found with the treatment bio-compost @10 t alone which decreased with the application of fertilizers, vermicompost, FYM and their combination with $100 \%$ NPK. The magnitude of decrease in the activity was 3.7 in the treatment vermicompost @ $10 \mathrm{t} \mathrm{ha}^{-1}$ alone, 9.2 percent when biocompost applied @ $10 \mathrm{t} \mathrm{ha}^{-1}$ with $100 \%$ NPK and 10.8 percent with vermicompost applied @10 t ha $^{-}$ 1 alongwith $100 \%$ NPK. The greater dehydrogenase activity in case of biocompost alone is an indicator of partial decomposition of the compost means that compost is still being decomposed and thereby having higher dehydrogenase activity. Decrease in this activity in vermicompost, NPK application alone and bio and vermicompost in combination with NPK applications is indicating complete maturity of the compost. The organic carbon, total nitrogen were significantly higher in treatments of biocompost/vermicompost when applied in combination with $100 \%$ NPK in comparison to control followed by the bio/vermicompost alone application. However total phosphorus content did not differ significantly. 
Data pertaining to microbial biomass presented in Table 5 revealed that sole application of bio-compost and integration of each type of compost and chemical fertilizer has significant increase in soil microbial biomass carbon over sole application of NPK fertilizer and control. The magnitude of microbial biomass carbon varied from 38.2 to 30.5 and 64.0 to 55.3 percent in sole application of NPK fertilizer and control, respectively. Generally addition of organic manures increased microbial biomass of the soil. The increase was expected because of increase in the population various groups of microbes in soil. The addition of Azotobacter as an inoculant in vermicompost, bio-compost and FYM increased root biomass production, which resulted in greater production of root exudates, increasing the beneficial microbial population in the rhizosphere. The inoculations of Azotobacter were grown to reasonably sufficient number with longer shelf life with the application of these manures. Additions of these manures provided a stable supply of carbon and energy for rapid growth of other microbial groups, which increased the microbial biomass pool, which in turn increased the potential for greater nutrient cycling and large amounts of nitrogen are stored in the relatively labile microbial biomass. In the rhizosphere of soybean, better proliferation of microbial groups have been reported due to relatively high amount of organic carbon and to root exudates released as a source of energy (Qureshi et al., 2005). Under these conditions, the roots were able to exude enough photosynthates to sustain the ongoing infection process. It has well known that the relatively large amounts of carbon assimilated in the photosynthesis are being transferred from the roots into the soil. The organic material is readily decomposed by rhizosphere microorganisms. The release of organic compounds by the plant roots is of direct importance to microorganisms living in the rhizosphere as these feed on exuded organic compounds. The enrichment of rhizosphere with organic compounds could readily be utilized by microbes, resulting in greater density in the rhizosphere than the bulk soil. Similar findings have been reported by Saini et al., (2005). Their findings revealed that integrated nutrient management both under soybean and winter maize significantly influenced the biomass carbon at different stages. Although both composts and farmyard manure has similar results in the integration with NPK fertilizers but the treatments having bio-compost and FYM has numerically higher microbial biomass carbon as compared to vermicompost treatment. The finding endorses the results of Singh and Ganguly (2005) who inferred that this is due to slow decomposition/mineralization of nutrients in the FYM and biocompost in comparison to vermicompost.

\section{Correlation of microbial properties with some of chemical properties}

Correlation was found positive between microbial population viz bacterial, fungal and actinomycetes has shown significant and positive correlation with microbial biomass carbon (Table 6). This is expected as the microbial biomass is estimate of carbon released from the microbial cells which depends upon the total number of the various groups. Microbial population showed significant and positive correlation with the organic carbon, total nitrogen and total phosphorus of the rhizospheric soil. Probably increase in total $\mathrm{C}, \mathrm{N}$ and $\mathrm{P}$ content had maintained the proper $\mathrm{C}: \mathrm{N}: \mathrm{P}$ ratio for mineralization process which resulted in the increased microbial population of each group. Dehydrogenase activity has positive and significant correlation with microbial population. Dehydrogenase activity did show positive and significant correlation with microbial biomass carbon because 
dehydrogenase activity is considered truly of microbial origin (Tabatabai, 1994). Dehydrogenase activity has positive correlation with the organic carbon but it was not significant with the total nitrogen and total phosphorus probably due to the high availability of nitrogen and phosphorus in soil.

It is concluded that vermicompost/biocompost @ $10 \mathrm{t} \mathrm{ha}^{-1}$ was capable of producing okra yield equivalent to $100 \%$ NPK, however each at the rate of $5 \mathrm{tha}^{-1}$ could not produce the yield equal to $100 \%$ NPK. The combined use of $100 \%$ NPK with vermicompost produced highest yield, $\mathrm{N}, \mathrm{P}$ and $\mathrm{K}$ uptakes, mineral contents which were at par $100 \% \mathrm{NPK}+$ with biocompost at the same rate. The combined use of vermi/bio-compost with inorganic fertilizers improved yield and quality parameters in comparison to alone application of either organic source or inorganic source of nutrients. Bio-compost has an edge over vermicompost in improving the microbial groups including Azotobacter, dehydrogenase activity and microbial biomass carbon. Microbial population showed significant and positive correlation with the organic carbon, total nitrogen and total phosphorus of the rhizospheric soil and also with microbial biomass carbon and dehydrogenase activity.

\section{References}

Agbo, Adouko, Edith, Gnakri, Dago, Beugre Grah Maxwell, Fondia, Lassino and Kouame, Christophe. 2008. Maturity degree of four okra fruit varieties and their nutrient composition. Electronic Journal of Food and Plants Chemistry 3:1-4.

Arshad, M. A. and Coen, G. M. 1992. Characterization of soil quality; physical and chemical criteria. American Journal of Alternative Agriculture 7:25-31.

Bunt, J. S. and Rovira, A.D. 1955
.Microbiological studies of some sub Antrartic soils. J of Soil Science 6:119128.

Casida, L.E. Jr., Klein D.A., Santoro, I.1964. Soil dehydrogenase activity. Soil Science 98:371-370.

Hamon, S. 1988.Organisation evolutive du genre Abelmoschus (gambo). Coadaptation et évolution de deux especes cultivees en Afrique de I'Ouest, A.esculentus et A.caillei. Paris: ORSTOM, Travaux et documents microedites. 46: 91.

Gaur, A. C. 1998. Integrated plant nutrient supply system blending organic, bio and chemical resources. In: Summer School on Soil-Plant-Microbe Interaction in Relation to Integrated Nutrient Management, Division of Microbiology, IARI, New Delhi.

Gomez, K. A. and Gomez, A. A. 1984. Statistical procedures for agricultural research. John Wiley and Sons, New York.

Jenkinson, D.S., Powlson, D.S.1976.The effects of biocidal treatment on metabolism in soil. V. A method for measuring soil biomass. Soil Biology and Biochemistry 8:209-213.

Kamlesh, K., Mishra, M. M., Dhankar, S.S, Kapoor K.K. and Gupta, A. P.1991. Effect of long-term manorial application on microbial biomass. Journal of Indian Society of Soil Science 39:685-688.

Kale, R. D., Mallesh, B.C., Bano, K. and Bagyraj, D.J. 1992. Influence of vermicompost application on the available micronutrient and selected microbial population in paddy field soil. Soil Biology and Biochemistry 24: 1317-1320.

Singh, K. R. K., Athokpam, Singh, H., Changte, Zoliana and Singh, Gopimohan N. 2005. Integrated management of Azolla, vermicompost and urea on yield and nutrient uptake by 
rice and soil fertility. Journal of Indian Society of Soil Science 53:107-110.

Martin, J.P.1950.Use of acid, rose Bengal and streptomycin in the plate method for estimating soil fungi. Soil Science. 69:215-233.

Minhas, R. S. and Sood A.1994. Effect of inorganic and organic on the yield and nutrient uptake by three crops in rotation on an acid Alfisol. Journal of Indian Society of Soil Science 42:257262.

Mishutin,E. N. and Shilniknova, V. K. 1971. Biological fixation of nitrogen (Translated by A.Gozy). Mad Milan Press, Madras.

Qureshi, A.A., G. Narayanasamy, P. K. Chhonkar and B.R.

Balasundaram.2005.Direct and residual effect of phosphate solubilizers and FYM on the available P, organic carbon, and viable counts of phosphate solubilizers in the soil after soybean, mustard and wheat crops. Journal of Indian Society of Soil Science 53:97100.

Rana, M. C., Datt, N. and Singh, M. 2006. Effect of Rhizobium culture in combination with organic and chemical fertilizers on rajmash (Phaseolus vulgaris) under dry temperate conditions of Himachal Pradesh. Indian Journal of Agricultural Sciences 76:151153.

Rathore, A. L., Chipde, S. J. and Pal, A. R.1995.Direct and residual effects of bioorganic and inorganic fertilizers in rice wheat cropping system. Indian Journal of Agronomy 40: 248-250.

Rita, Patil, B. and Varade P. A. 1998. Microbial population in rhizosphere as influenced by high input rates of fertilizer application to sorghum on a vertisol. Journal of Indian Society of Soil Science 46: 223-227.

Ramaswami P. P. 1999. Recycling of agricultural and agro-industry waste for sustainable agricultural production. Journal of Indian Society of Soil Science.47: 661-665.

Sharma, N., Srivastava, L. L. and Mishra, B. 1983. Studies on microbial changes in soil as a result of continuous application of fertilizers, farm yard manure and lime. Journal of Indian Society of Soil Science 31: 202-206.

Sharma, S.D. Devi, M. Kumar, P. Bhardwaj, S. K. and Raj, H. 2011.Potential use of bioorganic nutrient source dynamics on cropping behaviour, soil properties, and yield quality attributes of apricot. Communications in Soil Science and Plant Analysis 42: 1659-1674.

Sharma, V., Kanwar, K. and Dev, S. P. 2004 Efficient recycling of abnoxious weed plant(Lantana camera L.) and congress grass(Parthenium hystrophorus L.) as organic manure through vermicomposting .Journal of Indian Society of Soil Science 52: 112-114.

Singh, A. B. and Ganguly T. K. 2005. Quality comparison of conventional compost, vermicompost and chemically enriched compost. Journal of Indian Society of Soil Science 53, 352-355.

Sreenivas, C., Muralidhar, S. and Rao, M.S. 2000. Vermicompost: A viable component of IPNSS in nitrogen nutrition of ridge gourd. Annals of Agricultural Research 21:108-113.

Saini, V. K., Bhandari S. C., Sharma S. K. and Tarafdar, J. C. 2005. Assessment of microbial biomass under integrated nutrient management in soybean-winter maize cropping sequence. Journal of Indian Society of Soil Science 53:346351.

Swain, A, K., Pattanayak, S. K., Jena M. K. and Nayak R. K. 2003. Effect of integrated use of bio-inoculants and fertilizer nitrogen on growth, yield and nitrogen economy of okra. Journal of 
Indian Society of Soil Science 51:145149.

Tisdall, J.M. 1991. Fungal hyphae and structural stability of soil. Australian Journal of Soil Research 29: 729-743.

Veralakshmi, B. R., Srinivasamurthy, C.A. and Bhaskar, S. 2005. Effect on integrated use of organic manures and inorganic fertilizers on organic carbon, available $\mathrm{N}, \mathrm{P}$ and $\mathrm{K}$ in sustaining productivity of groudnut-fingermillet cropping scheme. Journal of Indian Society of Soil Science 53:315-318.

\section{How to cite this article:}

Badhan, N. K., N. Datt and Sharma, R. P. 2020. Studies on Impact of Organic, Inorganic and Integrated Source of Nutrients on Growth, Yield, Quality and Nutrient Uptake of Okra (Abelmoschus esculentus) and Soil Microbiological Properties. Int.J.Curr.Microbiol.App.Sci. 9(12): 2391-2403. doi: https://doi.org/10.20546/ijcmas.2020.912.284 